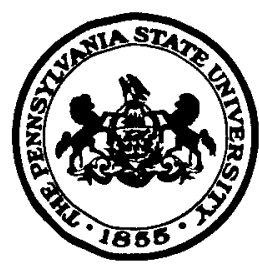

THE PENNSYLVANIA

STATE UNIVERSITY

\title{
IONOSPHERIC RESEARCH
}

Scientific Report 389

\section{ON THE PRODUCTION OF $\mathrm{N}_{2} \mathrm{O}$ FROM THE REACTION OF O('D) WITH $\mathrm{N}_{2}$}

\author{
by
}

R. Simonaitis, Eduardo Lissi and Julian Heicklen

February 22, 1972

The research reported in this document has been sponsored by the National Aeronautics and Space Administration under Grant NGL 39-009-003 and in part by the National Science Foundation under Grant No. GA-12385.

\section{IONOSPHERE RESEARCH LABORATORY}

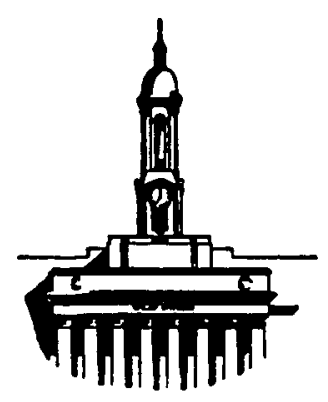

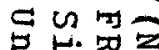

H.

$<0$ 更

$\therefore D$

品旺向

त如可

$N H$

$N$ on $\rightarrow$

$m 2 \sqrt{2}$

(D) $\cap \infty$

$\sigma+H 6$

o $0=$

$\overrightarrow{0}$

V- 00

Norz

$\stackrel{D}{\supset} 0$

$\vec{a}=$

$<$

능밍

$\stackrel{2}{2} \approx 0$

ㅂ. 벙등

I $\mathrm{r}$

$\sim 20$

觉录品

$8+$

กิ

$\rightarrow$

5

$\stackrel{0}{g}$ 
"On the Production of $\mathrm{N}_{2} \mathrm{O}$ from the Reaction

$$
\text { of } \mathrm{O}\left({ }^{l} \mathrm{D}\right) \text { with. } \mathrm{N}_{2}^{\prime \prime}
$$

by"

R. Simonaitis, Eduardo Lissi and Julian Heicklen

February. 22, 1972

"The research reported in this document has been sponsored by the National Aeronautics and Space Administration under Grant NGL 39-009-003 and in part by the National Science Foundation under Grant GA-12385." Submitted by: $\frac{\text { Alian the then }}{\text { Julian Heicklen, Professor of Chemistry }}$

Project Supervisor

Approved by:

J.S. Nisbet, Director

Ionosphere Research Laboratory

Ionosphere Research Laboratory

The Pennsylvania State University

University Park, Pennsylvania 16802 


\section{ABSTRACT}

Ozone was photolyzed at $2537 \mathrm{~A}$ and $25^{\circ} \mathrm{C}$ in the presence of $42-115$ tor $\mathrm{r}$ of $\mathrm{O}_{2}$ and about 880 tor $\mathrm{r}$ of $\mathrm{N}_{2}$ to test the relative importance of the two reactions

$$
\begin{aligned}
& \left.O{ }^{1} D\right)+N_{2}+M \rightarrow N_{2} O+M \\
& O\left({ }^{1} D\right)+N_{2} \rightarrow O\left({ }^{3} P\right)+N_{2}
\end{aligned}
$$

$\mathrm{N}_{2} \mathrm{O}$ was not found as a product. Thus from our detectability limit for $\mathrm{N}_{2} \mathrm{O}(0.3 \mu)$, an upper limit to the efficiency of the first reaction relative to the second of $2.5 \times 10^{-6}$ at 1000 tor $r$ total pressure was computed. This cor responds to $\mathrm{k}_{1} / \mathrm{k}_{2}<0.8 \times 10^{-25} \mathrm{~cm}^{3} /$ particle. 
TABLE OF CONTENTS

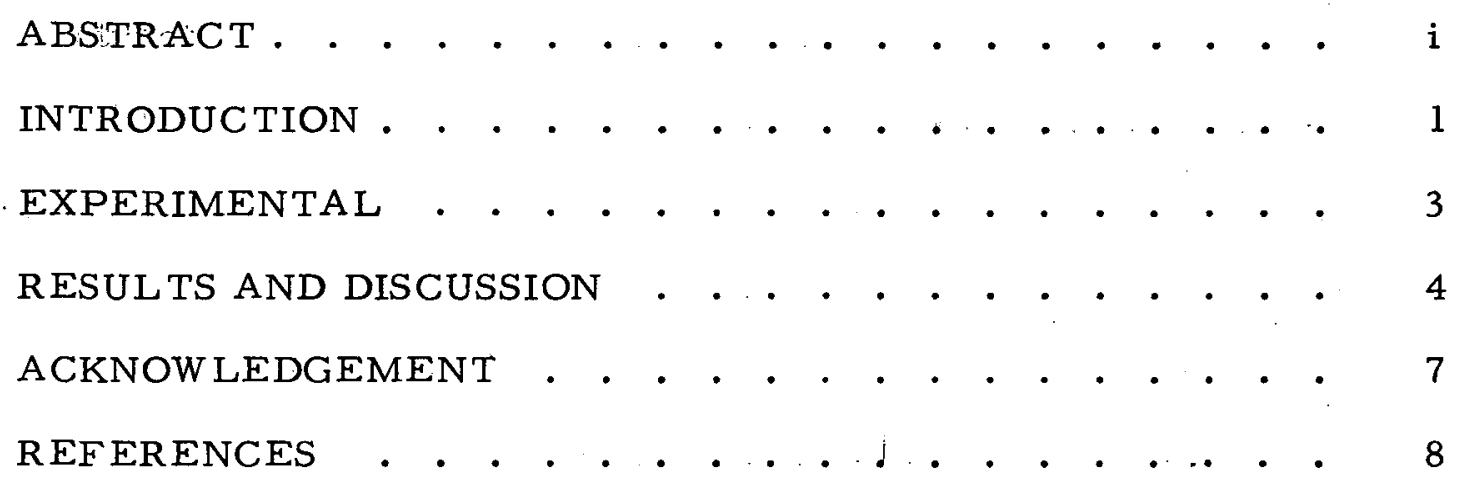




\section{INTRODUCTION}

The source of $\mathrm{N}_{2} \mathrm{O}$ in the earth's upper atmosphere is still an unsolved problem. Some time ago Bates and Witherspoon ${ }^{1}$ considered the reaction

$$
\left.\mathrm{O}^{1} \mathrm{D}\right)+\mathrm{N}_{2}+\mathrm{M} \rightarrow \mathrm{N}_{2} \mathrm{O}+\mathrm{M}
$$

but more recently Bates and Hayes ${ }^{2}$ ignored this reaction because it was negligible compared to the deactivation of $O\left({ }^{1} D\right)$ by $N_{2}$.

$$
\left.\mathrm{O}\left({ }^{1} \mathrm{D}\right)+\mathrm{N}_{2} \rightarrow \mathrm{O}^{3} \mathrm{P}\right)+\mathrm{N}_{2}
$$

However very recently Nicolet ${ }^{3}$ has again considered reaction 1 , and has concluded that if it occurs $10^{-4}$ as often as reaction 2 , it should be the principle source of $\mathrm{N}_{2} \mathrm{O}$ in the stratosphere.

There is experimental evidence that reaction" 1 does occur. Groth and Schierholz ${ }^{4}$ photolyzed $\mathrm{O}_{2}$ at $1470 \mathrm{~A}$ and 7 torr pressure in the presence of 419 tor $\mathrm{r}$ of $\mathrm{N}_{2}$ and found that about $10^{-4}$ of the oxygen atoms reacted with $\mathrm{N}_{2}$ to produce $\mathrm{N}_{2} \mathrm{O}$. However, Katakis and Taube ${ }^{5}$ photolyzed $\mathrm{O}_{3}$ at 2537 A at pressures of 10-100 torr in the presence of 300-500 tor $\mathrm{r}$ of $\mathrm{N}_{2}$, and could not find any oxides of nitrogen; under their conditions, the quantum yield of $\mathrm{N}_{2}$ O formation, $\Phi\left\{\mathrm{N}_{2} \mathrm{O}\right\}$, was $<10^{-4}$.

DeMore and Raper ${ }^{6}$ examined the photolysis of $\mathrm{O}_{3}$ in liquid $\mathrm{N}_{2}$ and found that for incident radiation between 2480 and $3000 \mathrm{~A}, \Phi\left\{\mathrm{N}_{2} \mathrm{O}\right\}=$ 0.014. This value is then the upper limiting value, since it was obtained in the condensed phase at $-196^{\circ} \mathrm{C}$, conditions which tend to favor reaction 1 over reaction 2 ; in the gas phase at more elevated temperatures, the yield must be considerably smaller. 
We have re-examined this problem in order to resolve the discrepancy between the results of Groth and Schierholz and of Katakis and Taube and to obtain a more accurate value for the efficiency of reaction 1 in the gas phase. At 1000 torr total pressure $\left(\mathrm{N}_{2}+\mathrm{O}_{2}\right.$, mostly $\mathrm{N}_{2}$ ), we have found no evidence for $\mathrm{N}_{2} \mathrm{O}$ formation. Consequently the upper limit for the efficiency of reaction 1 at 1000 tor $\mathrm{r}$ is $\leq 2.6 \mathrm{x}$ $10^{-6}$ compared to reaction 2. This upper limit for the efficiency for this reaction has thus been reduced by a factor of 40 . 


\section{EXPERIMENTAL}

Matheson $\mathrm{O}_{2}$ and Prep. Grade $\mathrm{N}_{2}$ were purified by passage over traps maintained at $-196^{\circ} \mathrm{C}$. Both the $\mathrm{N}_{2}$ and $\mathrm{O}_{2}$ contained each other as impurities but this is irrelevant. Ozone was prepared by passing an electric discharge through the $\mathrm{O}_{2}$. The $\mathrm{O}_{3}$ produced was collected at $-196^{\circ} \mathrm{C}$, and the excess $\mathrm{O}_{2}$ pumped away. The $\mathrm{O}_{3}$ was then distilled at $-186^{\circ} \mathrm{C}$, stored at $-196^{\circ} \mathrm{C}$, and degassed at this temperature before each run.

A conventional high-vacuum line utilizing Teflon stopcocks with Viton "O" rings was used. Both mercury and stopcock grease were vigorously excluded. Pressures of $\mathrm{O}_{3}$ were measured on a sulfuric acid manometer; $\mathrm{N}_{2}$ and $\mathrm{O}_{2}$ pressures, on a NRL alphatron gauge. The reaction cell was a cylindrical quartz cell $10 \mathrm{~cm}$ long and $5 \mathrm{~cm}$ in diameter. During a run the $\mathrm{O}_{3}$ was monitored by light absorption. Dark decomposition of the $\mathrm{O}_{3}$ was negligible.

A Hanovia flat-spiral low-pressure $\mathrm{Hg}$ resonance lamp Model No. Z1400-013 was used as a radiation source. A Corning 7-54 filter, which removes wavelengths below 2200 and above $4000 \mathrm{~A}$ was used.

After irradiation, the mixture was passed through three traps at $-196^{\circ} \mathrm{C}$, the first trap being filled with glass wool. The non-condensable gases were removed. The remaining fraction was analyzed for $\mathrm{N}_{2} \mathrm{O}$ by gas chromatography on a Porapak $Q$ column, 1/4-inch in diameter by $24 \mathrm{ft}$. long operated at room temperature. Blank runs which were not irradiated gave $\sim 0.2-0.3 \mu$ of $\mathrm{N}_{2} \mathrm{O}$. 


\section{RESULTS AND DISCUSSION}

Experiments were done in which the incident radiation was from a filtered mercury resonance lamp, so that the only effective wavelength was at $2537 \mathrm{~A}$. Ozone at 5-12 torr pressure was photolyzed for 9-24 hours in the presence of 31 to 155 torr $\mathrm{O}_{2}$ and 870-1050 torr $\mathrm{N}_{2}$. The purpose of the added $\mathrm{O}_{2}$ was to reduce the net rate of $\mathrm{O}_{3}$ consumption by introducing reaction 3 .

$$
\left.\mathrm{O}^{3} \mathrm{P}\right)+\mathrm{O}_{2}+\mathrm{M} \rightarrow \mathrm{O}_{3}+\mathrm{M}
$$

Thus, for example, in the absence of added $\mathrm{O}_{2}, 2$ torr of $\mathrm{O}_{3}$ is completely consumed in 2 minutes; whereas, if 100 torr of $\mathrm{O}_{2}$ is present it takes 24 hours to completely consume the ozone. Based on a total of 6 experiments, no $\mathrm{N}_{2} \mathrm{O}$ above that present as background $(0.3 \mu)$ was observed. Consequently, the upper limit for the $\mathrm{N}_{2} \mathrm{O}$ yield is $\sim 0.3 \mu$. In order to be certain that the small amount of $\mathrm{N}_{2} \mathrm{O}$ is not lost during analysis control experiments were done in which several $\mu$ of $\mathrm{N}_{2} \mathrm{O}$ were added to an identical gas mixture as in an actual run. Complete recovery of the added $\mathrm{N}_{2} \mathrm{O}$ was achieved. Finally, 10.5 $\mu$ of $\mathrm{N}_{2} \mathrm{O}$ were added to a mixture of $\mathrm{O}_{3}-\mathrm{O}_{2}-\mathrm{N}_{2}(13.5: 42: 880$ tor $\mathrm{r})$ and photolyzed for 24 hours with no change in $\mathrm{N}_{2} \mathrm{O}$ concentration to be certain that $\mathrm{N}_{2} \mathrm{O}$ is not consumed by the $O\left({ }^{1} D\right)$ atoms produced from $O_{3}$ photolysis via the reactions

$$
\begin{aligned}
& \mathrm{O}\left({ }^{1} \mathrm{D}\right)+\mathrm{N}_{2} \mathrm{O} \rightarrow \mathrm{N}_{2}+\mathrm{O}_{2} \\
& \mathrm{O}\left({ }^{1} \mathrm{D}\right)+\mathrm{N}_{2} \mathrm{O} \rightarrow 2 \mathrm{NO}
\end{aligned}
$$


Consequently, $\mathrm{N}_{2} \mathrm{O}$ consumption for $\mathrm{N}_{2} \mathrm{O}$ pressures $\leq 10 \mu$ via the above reactions is not important.

The known mechanism of $\mathrm{O}_{3}$ photolysis at $2537 \mathrm{~A}$ and in the presence of $\mathrm{O}_{2}$ and $\mathrm{N}_{2}$ is the following: 7

$$
\begin{aligned}
& \left.\mathrm{O}_{3}+\mathrm{h} v \rightarrow \mathrm{O}_{2}\left(\Delta^{1}\right)+\mathrm{O}^{1} \mathrm{D}\right) \\
& \left.\mathrm{O}^{1} \mathrm{D}\right)+\mathrm{N}_{2}+\mathrm{M} \rightarrow \mathrm{N}_{2} \mathrm{O}+\mathrm{M} \\
& \left.\left.\mathrm{O}^{1} \mathrm{D}\right)+\mathrm{N}_{2} \rightarrow \mathrm{O}^{3} \mathrm{P}\right)+\mathrm{N}_{2} \\
& \left.\mathrm{O}^{1} \mathrm{D}\right)+\mathrm{O}_{3} \rightarrow \mathrm{O}_{2}+\mathrm{O}_{2}^{*} \\
& \left.\mathrm{O}^{1} \mathrm{D}\right)+\mathrm{O}_{3} \rightarrow 2 \mathrm{O}_{2} \\
& \left.\left.{ }^{1} \mathrm{D}\right)+\mathrm{O}_{2} \rightarrow \mathrm{O}^{3} \mathrm{P}\right)+\mathrm{O}_{2}\left({ }^{1} \Sigma\right) \\
& \left.\mathrm{O}_{2}\left({ }^{1} \Delta\right), \mathrm{O}_{2}\left({ }^{1} \Sigma\right) \text { or } \mathrm{O}_{2}^{*}+\mathrm{O}_{3} \rightarrow 2 \mathrm{O}_{2}+\mathrm{O}^{3} \mathrm{P}\right) \\
& \left.O{ }^{3} \mathrm{P}\right)+\mathrm{O}_{3} \rightarrow 2 \mathrm{O}_{2} \\
& \left.O{ }^{3} \mathrm{P}\right)+\mathrm{O}_{2}+\mathrm{M} \rightarrow \mathrm{O}_{3}+\mathrm{M}
\end{aligned}
$$

where $\mathrm{O}_{2}^{*}$ is an unspecified electronic state of $\mathrm{O}_{2}$ (see reference 7).

With the realization that reaction 1 is unimportant, the mechanism leads to the expression

$$
\mathrm{k}_{1}[\mathrm{M}] / \mathrm{k}_{2}=\frac{\mathrm{n}\left\{\mathrm{N}_{2} \mathrm{O}\right\}}{\mathrm{n}\left\{\mathrm{O}^{\mathrm{l}}{ }^{\mathrm{D} D}\right\}} \cdot\left(1+\frac{\mathrm{k}_{3}\left[\mathrm{O}_{3}\right]}{\mathrm{k}_{2}\left[\mathrm{~N}_{2}\right]}+\frac{\mathrm{k}_{4}\left[\mathrm{O}_{2}\right]}{\mathrm{k}_{2}\left[\mathrm{~N}_{2}\right]}\right) \quad \mathrm{I}
$$

where $n\left\{N_{2} O\right\}$ and $n\left\{O\left({ }^{1} D\right)\right\}$ are the quantities of $N_{2} O$ and $\left.O{ }^{1} D\right)$ atoms produced. $n\left\{O\left({ }^{1} D\right)\right\}$ is obtained by graphical integration from Eqn. II.

$$
n\left\{O\left({ }^{1} D\right)\right\}=I_{a}^{\prime} \int_{0}^{\infty} \frac{I_{a}}{I_{0}} d t
$$


where $I_{a} / I_{0}$ is the fraction of light absorbed, $I_{a}{ }^{\prime}$ is the absorbed light intensity for $I_{a} / I_{0}=1.0$, and $t$ is the irradiation time.

A typical graph of $I_{a} / I_{0}$ vs. $t$ is shown in Figure 1 . The quantity $I_{a}{ }^{\prime}$ was found to be $200 \pm 30 \mu /$ min from the photolysis of $\mathrm{O}_{3}$ alone, where the quantum yield of $\mathrm{O}_{3}$ disappearance is 5.5 for small conversions. 7 Values obtained for $\left.n\left\{O^{1} D\right)\right\}$ are shown in Table $I$.

In order to compute $k_{1}[M] / k_{2}$ from Eqn. I, values of $k_{3} / k_{2}=$ 11. $0^{7,8}$ and $k_{4} / k_{2}=0.8^{9-11}$ were used. These values are averages of those given in the references. In computing $k_{1}[M] / k_{2}$ from Eqn. $I$, average values of $\left[\mathrm{O}_{3}\right]$ were used, since the term $\mathrm{k}_{3}\left[\mathrm{O}_{3}\right] / \mathrm{k}_{2}\left[\mathrm{~N}_{2}\right]$ is small. The value of $<2.5 \times 10^{-6}$ for the experiment at the highest $\mathrm{O}_{2}$ pressure can be taken as the upper limit for the efficiency of reaction 1 compared to reaction 2 at $25^{\circ} \mathrm{C}$ and 1000 tor total pressure $\left(87 \% \mathrm{~N}_{2}\right)$. If reaction 1 is entirely in the third order regime, then $k_{1} / k_{2} \leq 0.8 x$ $10^{-25} \mathrm{~cm}^{3} /$ particle. The known value for $\mathrm{k}_{2}$ is $9 \times 10^{-11} \mathrm{~cm}^{3} / \mathrm{particle-}$ sec, 10 and is probably accurate to better than a factor of two. Thus $\mathrm{k}_{1}<0.7 \times 10^{-35} \mathrm{~cm}^{6} /$ particle-sec. At stratospheric pressures of 30-50 tor $r$, reaction 1 occurs no more than $2 \times 10^{-7}$ as often as reaction 2. This is about a factor of 500 smaller than the value estimated by Nicolet ${ }^{3}$ to be necessary for reaction 1 to be an important atmospheric source of $\mathrm{N}_{2} \mathrm{O}$. 


\section{ACKNOW LEDGEMENT}

The authors wish to thank Professor Marcel Nicolet who brought this problem to their attention. This work was supported by the National Aeronautics and Space Administration through Grant No. NGL-009-003 and the Atmospheric Sciences Section of The National Science Foundation through Grant No. GA-12385, for which we are grateful. 


\section{REFERENCES}

1. D. R. Bates and A. E. Witherspoon, Monthly Notices Roy. Astronom. Soc., 112, 101 (1952).

2. D. R. Bates and P. B. Hayes, Planet. Space Sci.; 15, 189 (1967).

3. M. Nicolet, private communication (1971).

4. W. E. Groth and H. Schierholz, J. Chem. Phys. ; 27, 973 (1957).

5. D. Katakis and H. Taube, J. Chem. Phys.; 36, 416 (1962).

6. W. B. DeMore and O. F. Raper, J. Chem. Phys. ; 37, 2048 (1962).

7. For a recent review see E. Lissi and J. Heicklen, J. Photochem., in press (1972).

8. D. R. Snelling and E. J. Bair, J. Chem. Phys., 47, 228 (1967).

9. R. A. Young, G. Black, and T. Slanger, J. Chem. Phys., 49, 4758 (1968).

10. J. F. Noxon, J. Chem. Phys. , 52, 1852 (1970).

11. W. B. DeMore, J. Chem. Phys. , 52, 4309 (1970). 


\section{TABLE I}

$\begin{array}{lccccc}\begin{array}{l}{\left[\mathrm{O}_{3}\right]_{0},} \\ \text { Torr }\end{array} & \begin{array}{c}{\left[\mathrm{O}_{2}\right],} \\ \text { Torr }\end{array} & \begin{array}{c}{\left[\mathrm{N}_{2}\right],} \\ \text { Torr }\end{array} & \begin{array}{c}\text { Irradiation } \\ \text { Time, hrs. }\end{array} & \begin{array}{c}\left.n\left\{\mathrm{O}^{1} \mathrm{D}\right)\right\}, \\ \operatorname{Torr}\end{array} & 10^{6} \mathrm{k}_{1}[\mathrm{M}] / \mathrm{k}_{2}{ }^{\mathrm{b}} \\ 12.0 & 42 & 890 & 23 & 63 & <5 \\ 6.80 & 47 & 900 & 12 & 65 & <5 \\ 9.60 & 115 & 870 & 24 & 154 & <2.5\end{array}$

a) $\mathrm{O}_{3}$ always completely consumed

b) upper limit calculated from Eqn. I and the upper limit for the $\mathrm{N}_{2} \mathrm{O}$ yield of $0.3 \mu$. 


\section{FIGURE CAPTION}

Figure 1

Plot of the fraction of light absorbed vs. irradiation time for the photolysis at $2537 \mathrm{~A}$ and $25^{\circ} \mathrm{C}$ of a mixture consisting initially of 9.6 torr $\mathrm{O}_{3}, 115$ torr $\mathrm{O}_{2}$, and 870 torr $\mathrm{N}_{2}$. 
$-11-$

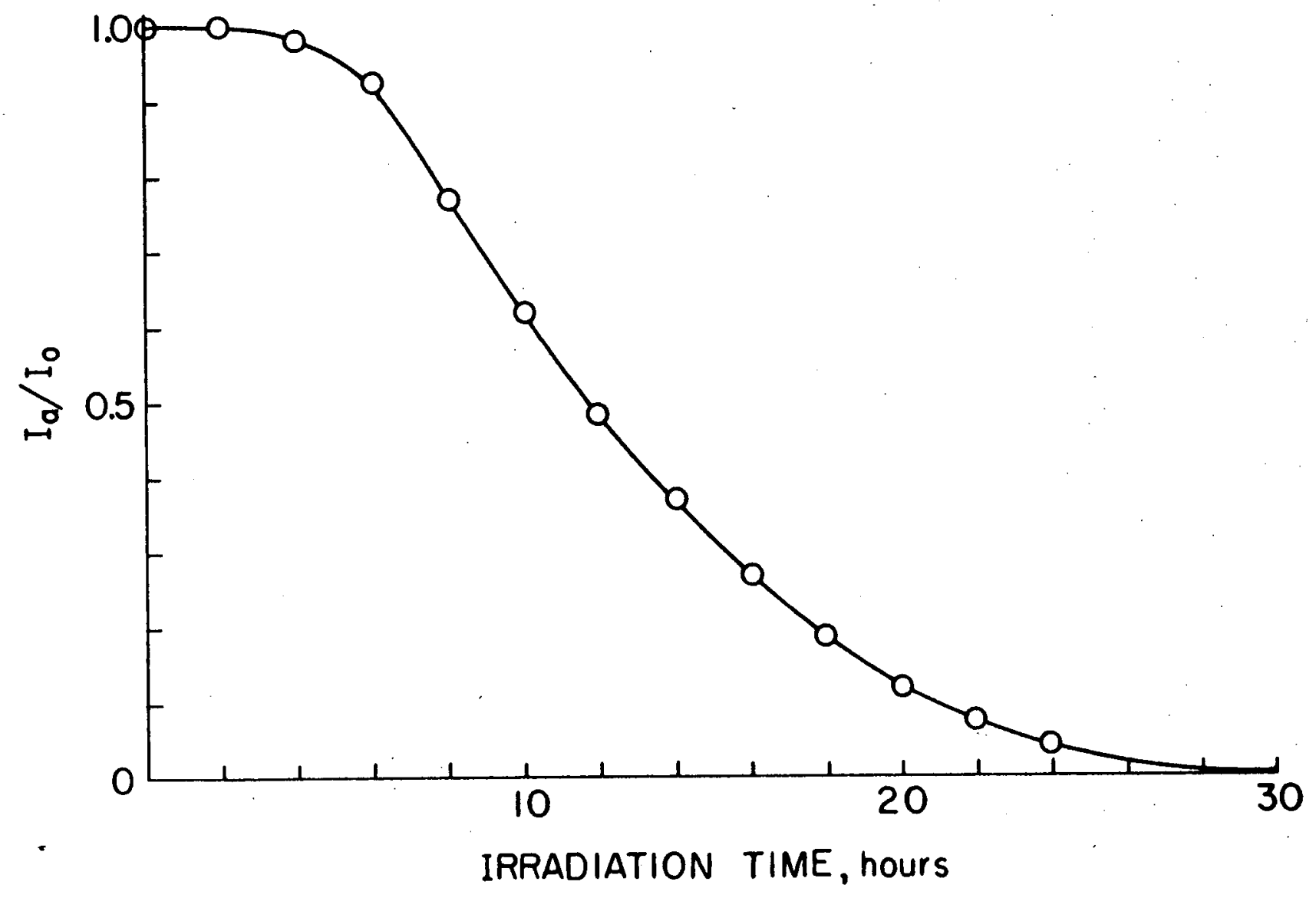

Figure 1 